\title{
New Near-infrared Fluorescent Probes with Single-photon Anti- Stokes-shift Fluorescence for Sensitive Determination of pH Variances in Lysosomes with a Double-Checked Capability
}

\author{
Tzu-Ho Chen ${ }^{a, d}$, Shuwei Zhang ${ }^{b, e}$, Meghnath Jaishic ${ }^{c}$, Rashmi Adhikari ${ }^{b}$, Jianheng $\mathrm{Bi}^{\mathrm{b}}$, \\ Mingxi Fang ${ }^{b}$, Shuai Xia ${ }^{b}$, Yibin Zhang ${ }^{a}$, Rudy L. Luck ${ }^{a}$, Ranjit Patic ${ }^{c}$, Hsien-Ming Lee ${ }^{a}$, Fen- \\ Tair Luo ${ }^{a}$, Ashutosh Tiwarib, and Haiying Liub \\ anstitute of Chemistry, Academia Sinica, Taipei, Taiwan 11529, Republic of China. \\ leehm1@chem.sinica.edu.tw and luoft@gate.sinica.edu.tw
}

bepartment of Chemistry, Michigan Technological University, 1400 Townsend Drive, Houghton, MI 49931, USA. tiwari@mtu.edu; hyliu@mtu.edu

'Department of Physics, Michigan Technological University, 1400 Townsend Drive, Houghton, MI 49931, USA. patir@mtu.edu

${ }^{d}$ Department of Chemistry, National Taiwan University, No. 1 Roosevelt Road Section 4, Taipei 10617, Taiwan, Republic of China

eSchool of Chemistry and Chemical Engineering, Yangzhou University, Yangzhou 225002, China.

\begin{abstract}
Two near-infrared luminescent probes with Stokes-shift and single-photon anti-Stokes-shift fluorescence properties for sensitive determination of $\mathrm{pH}$ variance in lysosomes have been synthesized. A morpholine residue in probe $\mathbf{A}$ which serves as a targeting group for lysosomes in viable cells was attached to the fluorophores via a spirolactam moiety while a mannose residue was ligated to probe $\mathbf{B}$ resulting in increased biocompatibility and solubility in water. Probes $\mathbf{A}$ and $\mathbf{B}$ contain closed spirolactam moieties, and show no Stokes-shift or anti-Stokes-shift fluorescence under neutral or alkali conditions. However, the probes incrementally react to $\mathrm{pH}$
\end{abstract}

Corresponding authors: leehm1@chem.sinica.edu.tw; luoft@gate.sinica.edu.tw; patir@mtu.edu; tiwari@mtu.edu; hyliu@mtu.edu. Publisher's Disclaimer: "Just Accepted" manuscripts have been peer-reviewed and accepted for publication. They are posted online prior to technical editing, formatting for publication and author proofing. The American Chemical Society provides "Just Accepted" as a service to the research community to expedite the dissemination of scientific material as soon as possible after acceptance. "Just Accepted" manuscripts appear in full in PDF format accompanied by an HTML abstract. "Just Accepted" manuscripts have been fully peer reviewed, but should not be considered the official version of record. They are citable by the Digital Object Identifier (DOIß).

"Just Accepted" is an optional service offered to authors. Therefore, the "Just Accepted" Web site may not include all articles that will be published in the journal. After a manuscript is technically edited and formatted, it will be removed from the "Just Accepted" Web site and published as an ASAP article. Note that technical editing may introduce minor changes to the manuscript text and/or graphics which could affect content, and all legal disclaimers and ethical guidelines that apply to the journal pertain. ACS cannot be held responsible for errors or consequences arising from the use of information contained in these "Just Accepted" manuscripts.

ASSOCIATED CONTENT

The supporting information can be obtained on the ACS publication website. Supporting information includes instrumentation, syntheses of intermediates, NMR spectra, and intracellular images, determination of fluorescence quantum yields, $\mathrm{pK}_{\mathrm{a}}$ values of the probes, theoretical computation of the probes, photostability of the probes, the probe selectivity and reversibility to $\mathrm{pH}$ changes, MTS assay, and fluorescence cellular imaging obtained by using AMF-4306, EVOSfl, AMG inverted fluorescence microscopy, Zeiss LSM 510 confocal microscope and Olympus IX71 inverted fluorescence microscopy. 
variance from 7.22 to 2.76 with measurable increases in both Stokes-shift and anti-Stokes-shift fluorescence at $699 \mathrm{~nm}$ and $693 \mathrm{~nm}$ under $645 \mathrm{~nm}$ and $800 \mathrm{~nm}$ excitation, respectively. This acidactivated fluorescence is produced by the breaking of the probe spirolactam moiety, which greatly increased overall $\pi$-conjugation in the probes. These probes possess upconversion near-infrared fluorescence imaging advantages including minimum cellular photo-damage, tissue penetration, and minimum biological fluorescence background. They display excellent photostability with low dye photobleaching and show good biocompatibility. They are selective and capable of detecting $\mathrm{pH}$ variances in lysosomes at excitation with two different wavelengths, i.e., 645 and $800 \mathrm{~nm}$.

\section{TOC Graphic}

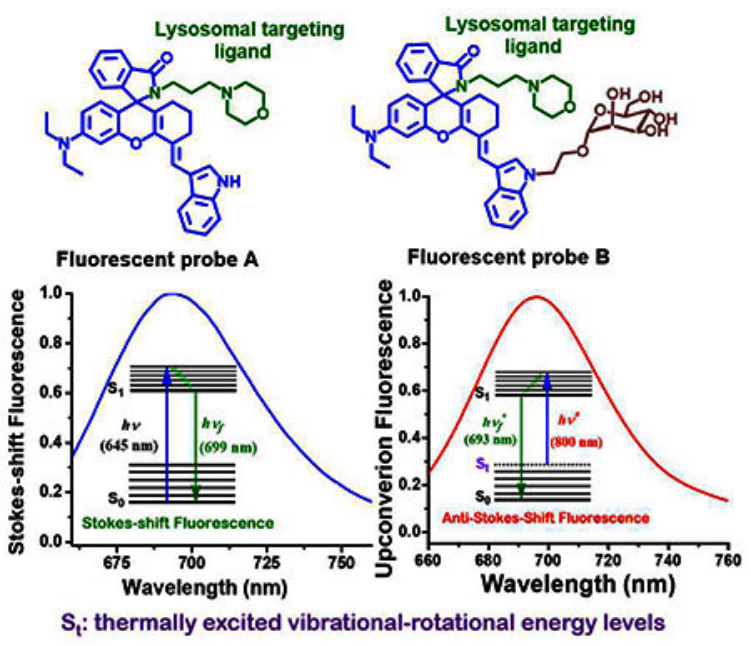

\section{Keywords}

Near-infrared imaging; fluorescent probes; single-photon anti-Stokes-shift fluorescence; acidic pH in lysosome; theoretical computation

\section{INTRODUCTION}

A stable $\mathrm{pH}$ inside living cells is important to maintain cellular homeostasis such as cellular proliferation, metabolism, phagocytosis, and enzymatic activity. ${ }^{1-3}$ Mitochondria function under slightly basic conditions ( $\mathrm{pH} 8.0$ ) while lysosomes work best under acidic $\mathrm{pH}$ conditions ( $\mathrm{pH} 4.5$ to 5.0) so that approximately 70 hydrolytic enzymes can break down a variety of biological macromolecules. ${ }^{4-6}$ Abnormal intracellular $\mathrm{pH}$ values are linked to cellular dysfunction and numerous diseases including cancer, cardiopulmonary, neurodegenerative diseases including Parkinson disease and Alzheimer's disease. ${ }^{7-8}$ The extracellular fluid $\mathrm{pH}$ value of cancer cells and tissues range from 6.2 to 6.9 , which is significantly lower than the physiological $\mathrm{pH}$ (7.4) of normal cells. ${ }^{9}$ Therefore, accurate detection of intracellular $\mathrm{pH}$ is vital in order to assess the health of living cells and cellular internalization pathways. Previous studies have been directed at the detection of intracellular $\mathrm{pH}$ using NMR, electrochemical microelectrodes, ${ }^{10}$ and fluorescence microscopy methods. ${ }^{11-16}$ Among these methods, fluorescent probes in conjunction with fluorescence 
microscopy for $\mathrm{pH}$ imaging have desirable advantages including operational ease, noninvasive and simultaneous results, high sensitivity, and high space-time resolution. ${ }^{2-3,11-23}$ Most of the previously reported fluorescent probes constructed to monitor intracellular $\mathrm{pH}$, absorb and emit at less than $600 \mathrm{~nm}$ wavelength. This can potentially cause cellular and tissue photodamage, and have biological autofluorescence issues. ${ }^{2-3,24}$ Many near-infrared (NIR) fluorescent probes were reported to address these issues. ${ }^{11-16,18,23,25-32}$ However, most of NIR fluorescent probes are based on Stokes-shift fluorescence with lower energy emission under higher energy excitation. ${ }^{2-3,11-19}$ Recently, a small organic molecule with single-photon anti-Stokes-shift fluorescence was reported to be useful for $\mathrm{Hg}$ (II) and $\mathrm{Cu}$ (II) detection. ${ }^{33-34}$ We reported on probes featuring anti-Stokes-shift fluorescence, with NIR emission at $740 \mathrm{~nm}$ under excitation at $800 \mathrm{~nm}$ for detection of intracellular $\mathrm{pH}$ changes. ${ }^{18}$ These fluorescent probes with one-photon anti-Stokes-shift properties have NIR imaging advantages which effectively negate dye photo bleaching issues under NIR excitation. ${ }^{18}$ Nevertheless, organic fluorophores with single-photon anti-Stokes-shift properties are still extremely underdeveloped and limited to molecules with one-photon NIR excitation and emission capability. ${ }^{18}$ For reasons alluded to above, it is very important to expand NIR fluorophores with one-photon anti-Stokes-shift properties to take advantage of upconversion near-infrared fluorescence imaging (Scheme 1). In this article, we report on the synthesis of two fluorescent probes with single-photon anti-Stokes-shift fluorescence properties. Probe $\mathbf{A}$ contains a lysosome-targeting morpholine residue for sensitive determination of $\mathrm{pH}$ variance in lysosomes with double-checked capability through Stokes-shift and anti-Stokes-shift NIR fluorescence channels (Schemes 1 and 2). We introduced a mannose residue to probe $\mathbf{B}$ to improve probe biocompatibility and solubility in aqueous solutions. The probes do not display Stoke-shift and anti-Stokes-shift fluorescence under neutral or alkali pH conditions. However, they respond sharply to $\mathrm{pH}$ changes from 7.22 to 2.76 with increases in both Stokes-shift and one-photon anti-Stokes-shift fluorescence for probes $\mathbf{A}$ at $699 \mathrm{~nm}$, and $\mathbf{B}$ at $693 \mathrm{~nm}$ under excitation at either $645 \mathrm{~nm}$ or $800 \mathrm{~nm}$. This is because acidic $\mathrm{pH}$ conditions result in the opening of the fluorophore spirolactam moiety in the neutral probes. Absorption peaks obtained by theoretical modeling of the ring opened probes match well with our experimental data. These molecules were successfully applied to detect lysosomal $\mathrm{pH}$ variance.

\section{EXPERIMENTAL SECTION}

\section{Synthesis of probe A.}

Compound 5 (100.0 mg, 0.17 mmol), N,N'-dicyclohexylcarbodiimide (DCC) (41.1 mg, 0.20 mmol) and $\mathrm{N}$-hydroxysuccinimide $(24.8 \mathrm{mg}, 0.22 \mathrm{mmol})$ were mixed in methylene chloride $(5 \mathrm{~mL})$. The solution was agitated at ambient temperature for 30 minutes followed by adding 3-morpholinopropylamine (6) $(46.9 \mathrm{mg}, 0.33 \mathrm{mmol})$ and the mixture allowed to react for 2 h. After removal of the solvent, the product was obtained as a brown solid by preparative TLC employing as the eluant a solution of dichloromethane and methanol in a ratio of 20 to 1 respectively (79.0 g, 75.8\%). ${ }^{1} \mathrm{H}$ NMR $\left(400 \mathrm{MHz}, \mathrm{CDCl}_{3}\right) \delta 8.72(\mathrm{~s}, 1 \mathrm{H}), 7.90-7.85(\mathrm{~m}$, 2H), $7.54(\mathrm{~s}, 1 \mathrm{H}), 7.49-7.39$ (m, 3H), 7.31-7.18 (m, 4H), $6.42(\mathrm{~d}, J=4.0 \mathrm{~Hz}, 1 \mathrm{H}), 6.34(\mathrm{~d}, J$ $=8.0 \mathrm{~Hz}, 1 \mathrm{H}), 6.28-6.25(\mathrm{~m}, 1 \mathrm{H}), 3.61(\mathrm{t}, J=4.0 \mathrm{~Hz}, 3 \mathrm{H}), 3.37-3.31(\mathrm{~m}, 4 \mathrm{H}), 3.28-3.21$ (m, 1H), 2.83-2.63 (m, 2H), 2.29-2.17 (m, 5H), 1.71-1.46 (m, 6H), 1.17 (t, $J=8.0 \mathrm{~Hz}, 6 \mathrm{H})$; 
${ }^{13} \mathrm{C}$ NMR $\left(100 \mathrm{MHz}, \mathrm{CDCl}_{3}\right) \delta 168.6,153.1,151.5,148.9,147.7,135.9,132.4,132.3$, $128.9,128.4,128.0,127.2,123.8,123.6,123.0,122.9,120.3,119.3,115.1,113.9,111.4$, 108.6, 106.8, 105.3, 97.9, 67.2, 66.9, 56.5, 53.6, 44.5, 38.4, 28.6, 25.3, 23.1, 22.5, 12.9. HRMS (ESI): calculated for $\mathrm{C}_{40} \mathrm{H}_{45} \mathrm{~N}_{4} \mathrm{O}_{3}{ }^{+}[\mathrm{M}+\mathrm{H}]^{+}, 629.3492$; found, 629.3483 .

\section{Synthesis of probe B.}

$\mathrm{K}_{2} \mathrm{CO}_{3}(60.2 \mathrm{mg}, 0.44 \mathrm{mmol})$ and compound $\mathbf{1 0}(0.11 \mathrm{~g}, 0.11 \mathrm{mmol})$ were added to methanol $(6 \mathrm{~mL})$, and stirred at ambient temperature for $2 \mathrm{~h}$. The salt was separated from the solution and the filtrate concentrated, affording probe $\mathbf{B}$ as a light brown solid $(82.0 \mathrm{mg}$, 89.6\%). ${ }^{1} \mathrm{H}$ NMR $\left(400 \mathrm{MHz}, \mathrm{CD}_{3} \mathrm{OD}\right) \delta 7.82-7.80(\mathrm{~m}, 2 \mathrm{H}), 7.64(\mathrm{~d}, J=8.0 \mathrm{~Hz}, 1 \mathrm{H}), 7.55-$ $7.46(\mathrm{~m}, 2 \mathrm{H}), 7.41-7.38(\mathrm{~m}, 2 \mathrm{H}), 7.21-7.17(\mathrm{~m}, 1 \mathrm{H}), 7.14-7.07(\mathrm{~m}, 2 \mathrm{H}), 6.57-6.55(\mathrm{~m}, 1 \mathrm{H})$, $6.27(\mathrm{~d}, J=8.0 \mathrm{~Hz}, 1 \mathrm{H}), 6.19(\mathrm{~d}, J=8.0 \mathrm{~Hz}, 1 \mathrm{H}), 4.68(\mathrm{~d}, J=8.0 \mathrm{~Hz}, 1 \mathrm{H}), 4.39-.29(\mathrm{~m}, 2 \mathrm{H})$, 4.04-3.99 (m, 1H), 3.76-3.57 (m, 5H), 3.50-3.42 (m, 4H), 3.31-3.28 (m, 2H), 3.12-3.03 (m, 2H), 2.87-2.83 (m, 2H), 2.65-2.59 (m, 2H), 2.08-1.97 (m, 6H), 1.66-1.23 (m, 8H), 1.09 $(\mathrm{t}, J=8.0 \mathrm{~Hz}, 6 \mathrm{H}) ;{ }^{13} \mathrm{C}$ NMR $(150 \mathrm{MHz}, \mathrm{CD} 3 \mathrm{OD}) \delta 170.4,161.5,164.5,158.1,152.9$, $150.6,149.6,137.7,134.0,133.3,130.1,129.9,127.2,124.9,123.5,121.1,120.0,116.5$, 113.7, 111.0, 106.8, 106.5, 102.0, 99.0, 74.8, 72.8, 72.2, 69.0, 68.3, 67.9, 67.8, 62.5, 57.3, 54.5, 50.0, 47.3, 45.5, 39.5, 29.7, 26.1, 24.2, 23.5, 13.1. HRMS (ESI): calculated for $\mathrm{C}_{48} \mathrm{H}_{57} \mathrm{~N}_{4} \mathrm{O}_{9}{ }^{-}[\mathrm{M}-\mathrm{H}]^{-}, 833.4126$; found, 833.4120.

\section{Stokes-shift fluorescence and anti-Stokes-shift fluorescence imaging of intracellular pH changes.}

HeLa, KB (a subline of the ubiquitous KERATIN-forming tumor cell line HeLa), MDAMB231 human breast cancer cell line and HUVEC-C cells (human umbilical vein endothelial cells) were obtained from ATCC. The HeLa cells with a minimum of five passages were put in 12-well culture plates with a density of $10000 \mathrm{cells} / \mathrm{cm}^{2}$ and preserved in an eagle medium based on Dulbecco's modification with $20 \%$ fetal bovine serum. Freshly prepared serum-free medium containing probe $\mathbf{A}$ or $\mathbf{B}(20$ or $50 \mu \mathrm{M}$ concentrations) was used to replace the cell culture medium after $16 \mathrm{~h}$ incubation, we further stained the cells with $1 \mathrm{~g} / \mathrm{L}$ Hoechst for $5 \mathrm{~min}$ and LysoTracker Green $(50 \mathrm{nM})$ for $30 \mathrm{~min}$ in order to mark the nucleus location and demonstrate whether probes can specifically target lysosomes. Probe $\mathbf{A}$ or $\mathbf{B}(10 \mu \mathrm{M})$ was initially added to the cells at $37^{\circ} \mathrm{C}$ for $30 \mathrm{~min}$ followed with incubation of $1 \mathrm{mg} / \mathrm{L}$ Hoechst and $50 \mathrm{nM}$ Lysotracker green for $30 \mathrm{~min}$ and $5 \mathrm{~min}$, respectively, in order to test whether the probes could identify $\mathrm{pH}$ variance in lysosomes. Once the cells were washed by a neutral PBS buffer twice, the cells were put in sodium phosphate buffers with $\mathrm{pH}$ ranging from $2.5,3.5,4.5,5.5,6.5$ to 7.5 accompanied with 5 $\mathrm{mg} / \mathrm{L}$ nigericin for $30 \mathrm{~min}$ to homologize the extracellular $\mathrm{pH}$ and buffer $\mathrm{pH}$. A Zeiss LSM510 confocal fluorescence microscope and a lamp-based Olympus IX-71 inverted fluorescence microscope were employed to collect cellular fluorescence imaging with both Stokes-shift and single-photon anti-Stokes-shift fluorescence. Suitable excitation wavelengths and each filter constant exposure time were employed to collect LysoTracker Green fluorescence, Stokes-shift fluorescence and anti-Stokes-shift fluorescence images in the same view field to achieve simultaneous localization visualization of our probes and LysoTracker Green. The JACoP plugin from ImageJ was used to obtain Pearson's coefficient in order to accomplish the fluorescence colocalization analysis and determine whether our 
probes stay in the same lysosomes with LysoTracker Green. For details on cell culture and Stoke-shift fluorescence cellular imaging of MDAMB231 and HUVEC-C cells, please see supplemental section (Figures S27-S38).

\section{RESULTS AND DISCUSSION}

\section{The probe synthesis}

The reaction of 2-(4-(diethylamino)-2-hydroxybenzoyl)benzoic acid (1) with cyclohexanone (2) in sulfuric acid afforded compound 3. ${ }^{15}, 18,35-36$ Compound $\mathbf{3}$ was then reacted with indole-3-carboxaldehyde (4) in acetic anhydride solution (Scheme 3) yielding the nearinfrared fluorescent dye (5). Probe $\mathbf{A}$ was prepared by reacting fluorescent dye $\mathbf{5}$ first with $\mathrm{N}$-hydroxysuccinimide under dicyclohexylcarbodiimide (DCC) for 30 minutes and then with 3-morpholinopropylamine (6) (Scheme 3). To improve biocompatibility and increase aqueous solubility of probe $\mathbf{B}$, we ligated a mannose residue to fluorescent dye (9) by reacting indole-3-carboxaldehyde bearing a protected mannose residue $(\mathbf{8})$ with compound $\mathbf{3}$, resulting in residue (9). Probe $\mathbf{B}$ bearing this mannose residue was then prepared by binding a morpholine residue to dye $\mathbf{9}$, forming $\mathbf{1 0}$, and then mild de-acetylation of the protected mannose residue from intermediate 10 in methanol with $\mathrm{K}_{2} \mathrm{CO}_{3}$.

\section{Probe absorption spectra upon $\mathrm{pH}$ changes.}

Peaks at $336 \mathrm{~nm}$ and 328 relating to absorption by the probe's indole groups were observed for probes $\mathbf{A}$ and $\mathbf{B}$ under neutral or alkali pH solutions, respectively (Figure 1 and Scheme 1). However, upon gradual $\mathrm{pH}$ decrease from 7.22 to 2.76, new peaks at $649 \mathrm{~nm}$ for $\mathbf{A}$ and $641 \mathrm{~nm}$ for $\mathbf{B}$ were observed. Under acidic conditions, the spirolactam moieties open resulting in extended $\pi$-conjugation in the molecules (Figure 1, and Scheme 1).

\section{Stokes-shift and anti-stokes-shift spectra of the probes upon pH changes}

The probes reveal very weak fluorescence under neutral or basic $\mathrm{pH}$ conditions. However, gradual $\mathrm{pH}$ decreases from 7.2 to 2.8 results in Stokes-shift and anti-Stokes-shift fluorescence increases for probes $\mathbf{A}$ and $\mathbf{B}$ at $699 \mathrm{~nm}$ and $693 \mathrm{~nm}$ under excitation at $645 \mathrm{~nm}$ and $640 \mathrm{~nm}$, respectively (Figures 2 and S13) Here the fluorophore spirolactam rings open under acidic $\mathrm{pH}$ conditions, resulting in significantly enhanced $\pi$-conjugation of the probe. Additionally, anti-Stokes-shift fluorescence responses of the probes under one-photon excitation at $800 \mathrm{~nm}$ are observed (Figure 3). The probes show Stokes-shift fluorescence quantum yields of $12 \%$ and $9.0 \%$, and anti-Stoke-shift fluorescence quantum yields of $2.5 \%$ and $2.1 \%$, and have molar absorptivities of $1.3 \times 10^{4}$ and $7.0 \times 10^{3} \mathrm{M}^{-1} \mathrm{~cm}^{-1}$ at $\mathrm{pH} 2.8$, respectively. The Henderson-Hasselbach ${ }^{37}$ equation was utilized to determine probe $\mathrm{pK}_{\mathrm{a}}$ values involving spirolactam ring opening and resulted in $\mathrm{pK}_{\mathrm{a}}$ values of 4.80 and 4.40 for probe $\mathbf{A}$ and $\mathbf{B}$, respectively (Scheme 1, Figures 3 and S14). The probes reversibly respond to $\mathrm{pH}$ variance ranging from 2.4 to 7.2 for both Stokes-shift and anti-Stokes-shift fluorescence (Figures S21 and S22). 


\section{DFT Modeling.}

To understand the probe near-infrared fluorescense phenomena, we recourse to a firstprinciples density functional (DFT) approach. ${ }^{38-39}$ The geometry optimizations of probes $\mathbf{A}$ and $\mathbf{B}$ with configurations having closed and opened spirolactam ring were conducted by employing Becke's three parameter hybrid density functional method (B3LYP) incorporating part of the exact Hartree-Fock exchange. ${ }^{40}$ Our calculation is conducted using the $6-311 \mathrm{G}^{* *}$ gaussian basis set and the polarizable continuum model to represent the solvent effect. ${ }^{40}$ The closed spirolactam moiety configuration of the probes was calculated with water as the solvent. We used formic acid to mimic acidic $\mathrm{pH}$ for the spirolactam moiety opened structures. As the protonation of probes $\mathbf{A}$ and $\mathbf{B}$ in an acidic environment opens the probe spirolactam rings via bond breaking between the nitrogen atom in the spirolactam ring and the carbon atom in the middle ring of the rhodamine core, a perchlorate $\left(\mathrm{ClO}_{4}^{-}\right)$counter ion is added to balance the charge for the open ring configuration. Our calculations reveal that the opening of the spirolactam ring is favored by the transfer of charge from the $\mathrm{C}-\mathrm{N}$ bond of the spirolactam ring to the central ring of the rhodamine core. The charge on the carbon atom before and after the spirolactam ring opening is found to be $\sim-0.04 \mathrm{e}$ and $\sim 0.19 \mathrm{e}$, respectively. The delocalization of the charge is found to shorten the $\mathrm{C}-\mathrm{C}$ bond distance in the rhodamine middle ring from $\sim 1.50 \AA$ to $\sim 1.40 \AA$, thereby making the core more conducive to electron delocalization. Figure 4 shows the optimized structures of different two representative probes.

To further elucidate the effect of the spirolactam ring opening on the electronic structure of the probes, we analyzed the frontier energy levels of the probes before and after ring opening. The frontier energy levels along with the HOMO and LUMO of both probes under basic and acidic conditions are shown in Figures S15-S17. Our analysis reveals the HOMOLUMO energy gaps decrease upon protonation of probes $\mathbf{A}$ and $\mathbf{B}$, which indicate shifts toward the near infrared region of the spectra. To better understand the observed shift in the absorption spectrum, we executed excitonic calculations with time-dependent density functional theory (DFT) ${ }^{41-42}$; the ground state optimized geometry of the probes were considered for this study. These calculations provide us with various excited states along with the corresponding oscillatory strength that is related to the experimentally measured absorbance. As no prior information is available on the choice of exchange-correlation functional to accurately determine optical properties in different environments (with different $\mathrm{pH}$ levels), we performed the excitonic calculations of the probes using three different exchange-correlation functionals. First we did the TD-DFT ${ }^{41-42}$ calculation using the $\mathrm{SVWN}^{40}$ functional that utilizes the local density approach (LDA) ${ }^{40}$; S represents the Slater exchange and VWN adds the local correlation. We also utilized the PW91 ${ }^{40}$ functional that employs a generalized gradient corrected approach $(\mathrm{GGA})^{40}$ to perform the excitonic calculation. Finally, we performed the time-dependent DFT $^{41-42}$ calculation using the orbital-dependent hybrid B3LYP functional. ${ }^{40} \mathrm{~A}$ comparative analysis of the results obtained from these different functionals to the experimental observations demonstrates which functionals yield better results under neutral environments and which one works well under acidic environments for these molecules. A Lorentzian function with a half-height width value of $10 \mathrm{~nm}$ was used to fit the absorption spectra of all the probes (Figure 5). Our results show that at neutral $\mathrm{pH}$ when both probes have their spirolactam ring closed, the 
hybrid functional B3LYP ${ }^{40}$ that includes a fraction of the exact Hartree-Fock ${ }^{43}$ exchange calculates absorption peaks at $330 \mathrm{~nm}$ (probe A) and $341 \mathrm{~nm}$ (probe B). Compared with the values obtained from other DFT methods (SVWN, PW91) ${ }^{40}$, these values well match the experimental data. For the acidic environment, when probes $\mathbf{A}$ and $\mathbf{B}$ are protonated leading to opening of the spirolactam moieties, the SVWN functional ${ }^{40}$ results in absorption peaks at $634 \mathrm{~nm}$ (probe A) and $639 \mathrm{~nm}$ (probe B). These values match better with our experimental data when compared with the values obtained from other DFT functional (B3LYP, PW91). ${ }^{40}$ Thus, we can conclude that a correct choice of exchange-correlation functional is imperative to obtain the optical spectra of the fluorescent probes examined at different $\mathrm{pH}$ levels.

\section{Probe photostability.}

The photostability of the probes was evaluated by measuring fluorescence intensity every 10 min through continuous excitation of the probes under $640 \mathrm{~nm}$ or $800 \mathrm{~nm}$ for 5 -min periods. Probe A exhibited a Stokes-shift fluorescence decrease of less than 1.0\% under a 3-hour session excitation at $640 \mathrm{~nm}$ (Figure S19) while the Stokes-shift fluorescence intensity of probe $\mathbf{B}$ decreased by 3.0\% under similar conditions (Figure S19). Probes A and $\mathbf{B}$ show better photostability than a commercially available near-infrared cyanine dye (IR-780) (Figure S19). Interestingly, using the lower energy one-photon excitation effectively prevents probe photo bleaching issues. Anti-Stokes shift fluorescence intensities of probes $\mathbf{A}$ and $\mathbf{B}$ show less than $0.7 \%$ and $2 \%$ decrease respectively during an identical 3-hour period of excitation at $800 \mathrm{~nm}$ (Figure S20).

\section{Selectivity Experiments.}

Probe selectivities were investigated at $\mathrm{pH} 3.2$ and 7.4 in buffer solutions either with or without metal ions. The presence of $50 \mu \mathrm{M}$ metal ions including $\mathrm{Na}^{+}, \mathrm{K}^{+}, \mathrm{Mg}^{2+}, \mathrm{Ca}^{2+}, \mathrm{Al}^{3+}$, $\mathrm{Cd}^{2+}, \mathrm{Mn}^{2+}, \mathrm{Ni}^{2+}, \mathrm{Cu}^{2+}, \mathrm{Cr}^{3+}, \mathrm{Fe}^{3+}$, and $\mathrm{Ag}^{+}$ions do not result in significant fluorescence change at $\mathrm{pH} 3.2$ (Figure S23), demonstrating that probe response is unaffected by these cation metal ions. The effect of anions on the probes was also determined with $50 \mu \mathrm{M}$ of various anions including $\mathrm{Cl}^{-}, \mathrm{I}^{-}, \mathrm{Br}^{-}, \mathrm{NO}_{3}{ }^{-}, \mathrm{NO}^{2-}, \mathrm{SO}_{4}{ }^{2-}, \mathrm{SO}_{3}{ }^{2-}, \mathrm{S}^{2-}, \mathrm{HCO}_{2}{ }^{3-}, \mathrm{PO}_{4}{ }^{3-}$ or $\mathrm{CO}_{3}{ }^{2-}$ ions in $\mathrm{pH} 3.2$ or 7.4 buffer. These results show that probe response is also unaffected by the presence of any of these anions under excitation at $645 \mathrm{~nm}$ at $\mathrm{pH} 3.2$ (Figure S24).

Additionally, the probes exhibit sustained emission responses at $\mathrm{pH} 3.2$ with $50 \mu \mathrm{M}$ biothiols and amino acids such as alanine, arginine, cystine, cysteine, glycine, leucine, methionine, proline, tyrosine, and GSH (reduced glutathione) (Figure S25). Therefore, probes A and B can be used to explore $\mathrm{pH}$-related biological processes without any significant interference from cations, anions, biothiols and amino acids in the biological samples.

\section{Probe cytotoxicity.}

We employed an MTS assay to study the probe cytotoxicity through incubation of the cells with the probes under concentration ranges from 5 to $20 \mu \mathrm{M}$ for $48 \mathrm{~h}$. Cell viability of $88.3 \%$ and $92.0 \%$ for probes $\mathbf{A}$ and $\mathbf{B}$ at $10 \mu \mathrm{M}$, respectively, convincingly demonstrated that the probes possess low cytotoxicity to the cells under these experimental conditions (Figure S26). The mannose residue of probe $\mathbf{B}$ can not only considerably enhance the probe 
solubility in aqueous solutions but also improve the probe biocompatibility as probe $\mathbf{B}$ exhibited lower cytotoxicity.

\section{Probe cellular imaging of lysosomes}

Membrane-bound acidic Lysosomes maintain an acidic $\mathrm{pH}$ ranging from 4.5 to 5.0 allowing a wide variety of hydrolytic enzymes to function and break down proteins, nucleic acids, polysaccharides. ${ }^{44}$ It is known that small molecules under 1 KDa easily diffuse through lysosomal membranes due to osmotic pressure. ${ }^{44}$ Fluorescent probes bearing weakly basic lipophilic amines such as morpholine residues are easily trapped inside lysosomes due to the impermeability of the membrane as the amino groups become positively charge through protonation under lysosomal acidic $\mathrm{pH}$ conditions. ${ }^{44}$ Probes $\mathbf{A}$ and $\mathbf{B}$ with $\mathrm{pK}_{\mathrm{a}}$ values of 4.60 and 4.40 respectively are suitable for monitoring lysosomal $\mathrm{pH}^{44}$ We investigated whether probes $\mathbf{A}$ and $\mathbf{B}$ could specifically target lysosomes in live cells by using Lysotracker Green (a well-characterized lysosome specific probe) and conducting colocalization analyses (Figure 6). To validate the co-localization of probes $\mathbf{A}$ and $\mathbf{B}$ to lysosomes, we incubated Lysotracker Green and new probes with HeLa cells and collected images of the same observation field under different excitation and emission wavelengths to accomplish simultaneous visualization of Lysotracker Green and the probes in the same lysosomes. ${ }^{44}$ The probes become fluorescent inside HeLa cells as lysosomal acidic $\mathrm{pH}$ activates fluorescence by opening the probe spirolactam ring structures. Probe $\mathbf{B}$ showed a stronger fluorescence signal than probe $\mathbf{A}$ under the same concentration as the mannose residue from probe $\mathbf{B}$ may be facilitating probe cellular uptake (Figure 6). The sections in the cells labelled positively by the LysoTracker Green were almost perfectly matched with those stained with probe $\mathbf{A}$ or $\mathbf{B}$ and the fluorescence microscopy co-localization analysis gave the Pearson's coefficients of 0.85 or higher between LysoTracker Green and the probes live cells. These results demonstrate that probes $\mathbf{A}$ and $\mathbf{B}$ stay in the same lysosomes with LysoTracker green (Figure 6).

\section{Probe near-infrared fluorescence visualization of lysosomal pH changes.}

To investigate whether the probes can detect lysosomal $\mathrm{pH}$ changes, we conducted the cellular fluorescence imaging of lysosomal $\mathrm{pH}$ changes by incubating $10 \mu \mathrm{M}$ of the probes with HeLa and KB cells, and then putting the cells in buffers with $\mathrm{pH}$ from 2.5, 3.5, 4.5, 5.5, 6.5 to 7.5 holding $5 \mathrm{mg} / \mathrm{L}$ nigericin. The nigericin ionophore functions to homologize the intracellular $\mathrm{pH}$ and buffer $\mathrm{pH} .{ }^{25,30,37,45}$ Stokes-shift fluorescence images were first examined using the lamp-based Olympus IX-71 inverted microscope, and single-photon anti-Stokes-shift fluorescence was also examined using the same microscope with an external continuous $808 \mathrm{~nm}$ wavelength laser (Figure 7). Both probes $\mathbf{A}$ and $\mathbf{B}$ display very weak cellular Stokes-shift and anti-Stokes-shift fluorescence in the medium with physiological $\mathrm{pH}$ (7.4). Upon gradual lysosomal $\mathrm{pH}$ decrease from 7.5 to 3.5, gradual increases in cellular fluorescence intensities of the probes were observed in both Stokes-shift and anti-Stokes-shift fluorescence (Figures 7) as low pH levels breaks apart the spirolactam rings improving molecular conjugation. These cellular imaging results agree with how the probes respond to $\mathrm{pH}$ variance in buffers (Figures 2 and 3). We further used the probes to investigate $\mathrm{pH}$ changes in lysosomes with high-resolution using a Zeiss LSM510 confocal 
microscope (Figures 8, 10, S41-S66). Probes $\mathbf{A}$ and $\mathbf{B}$ exhibit similar turn-on cellular fluorescence responses in both Stokes-shift and anti-Stokes-shift fluorescence to $\mathrm{pH}$ changes in lysosomes of live HeLa and KB cells (Figures 8-11), which is also consistent with antiStokes-shift emission responses to $\mathrm{pH}$ variance in buffers (Figures 2 and 3). Cellular antiStokes-shift fluorescence can still be observed at pH 6.5 in HeLa and KB cells (Figures 8 and 10). Merged images of Stokes-shift and anti-Stokes-shift fluorescence images change colors from bright yellow to weak green with $\mathrm{pH}$ variance from 2.5 to 7.5 (Figures 8 and 9), indicating that probes $\mathbf{A}$ and $\mathbf{B}$ can also offer fluorescence visualization of lysosomal $\mathrm{pH}$ variance with a double-checked capability through two near-infrared fluorescence channels. In addition, we conducted Stokes-shift fluorescence imaging of lysosomal $\mathrm{pH}$ variances in HUVEC-C and MDA-MB231 breast cancer cells employing an inverted fluorescence microscope (AMF-4306, EVOSfl, AMG) and proved that the probes could sensitively respond to $\mathrm{pH}$ variance in lysosomes in live cells (Figures S27-S38). These combined results persuasively suggest that probes $\mathbf{A}$ and $\mathbf{B}$ can be used to sensitively monitor lysosomal $\mathrm{pH}$ changes.

\section{CONCLUSION}

In summary, we synthesized two new near-infrared fluorescent probes capable of exhibiting Stoke-shift and one-photon anti-Stokes-shift fluorescence. These probes also detected $\mathrm{pH}$ changes in live cell lysosomes. The morpholine residue on the probes specifically binds to lysosomes and the mannose group in probe $\mathbf{B}$ improves biocompatibility and aqueous solubility. Both probes reacted measurably to $\mathrm{pH}$ variance in both buffers and lysosomes with significant increases of both Stoke-shift and one-photon anti-Stokes-shift fluorescence. They possess excellent photostability with low photo bleaching and high $\mathrm{pH}$ selectivity. The probe platforms enable the construction of a variety of fluorescent probes with spirolactam on-off switches for sensitive sensing of cellular metal ions, ATP, and reactive species involving oxygen, nitrogen and sulfur atoms through two Stoke-shift and one-photon antiStokes-shift fluorescence channels with a double-checked capability.

\section{Supplementary Material}

Refer to Web version on PubMed Central for supplementary material.

\section{ACKNOWLEDGEMENTS}

Funding from the National Institute of General Medical Sciences of the National Institutes of Health under Award Number R15GM114751 (to H.Y. Liu and A. Tiwari) is gratefully acknowledged. The first-principles calculations were computed using RAMA and Superior, the high performance-computing cluster at Michigan Technological University.

\section{REFERENCES}

(1). Casey JR; Grinstein S; Orlowski J Sensors and Regulators of Intracellular pH. Nat. Rev. Mol. Cell Biol. 2010, 11, 50-61. [PubMed: 19997129]

(2). Hou JT; Ren WX; Li K; Seo J; Sharma A; Yu XQ; Kim JS Fluorescent Bioimaging of pH: From Design to Applications. Chem. Soc. Rev 2017, 46, 2076-2090. [PubMed: 28317979]

(3). Yue YK; Huo FJ; Lee S; Yin CX; Yoon J A Review: The Trend of Progress About pH Probes in Cell Application in Recent Years. Analyst 2017, 142, 30-41. 
(4). Johansson AC; Appelqvist H; Nilsson C; Kagedal K; Roberg K; Ollinger K Regulation of Apoptosis-Associated Lysosomal Membrane Permeabilization. Apoptosis 2010, 15, 527-540. [PubMed: 20077016]

(5). Turk B; Turk V Lysosomes as "Suicide Bags" in Cell Death: Myth or Reality? J. Biol. Chem 2009, 284, 21783-21787. [PubMed: 19473965]

(6). Stinchcombe J; Bossi G; Griffiths GM Linking Albinism and Immunity: The Secrets of Secretory Lysosomes. Science 2004, 305, 55-59. [PubMed: 15232098]

(7). Lee MH; Sharma A; Chang MJ; Lee J; Son S; Sessler JL; Kang C; Kim JS Fluorogenic ReactionBased Prodrug Conjugates as Targeted Cancer Theranostics. Chem. Soc. Rev 2018, 47, 28-52. [PubMed: 29057403]

(8). Colacurcio DJ; Nixon RA Disorders of Lysosomal Acidification-the Emerging Role of V-Atpase in Aging and Neurodegenerative Disease. Ageing Research Reviews 2016, 32, 75-88. [PubMed: 27197071]

(9). Webb BA; Chimenti M; Jacobson MP; Barber DL Dysregulated Ph: A Perfect Storm for Cancer Progression. Nat. Rev. Cancer 2011, 11, 671-677. [PubMed: 21833026]

(10). He S; Mason RP; Hunjan S; Mehta VD; Arora V; Katipally R; Kulkarni PV; Antich PP Development of Novel F-19 Nmr Ph Indicators: Synthesis and Evaluation of a Series of Fluorinated Vitamin B-6 Analogues. Biorg. Med. Chem 1998, 6, 1631-1639.

(11). Lee H; Akers W; Bhushan K; Bloch S; Sudlow G; Tang R; Achilefu S Near-Infrared pHActivatable Fluorescent Probes for Imaging Primary and Metastatic Breast Tumors. Bioconjugate Chem 2011, 22, 777-784.

(12). Li P; Xiao HB; Cheng YF; Zhang W; Huang F; Zhang W; Wang H; Tang B A near-InfraredEmitting Fluorescent Probe for Monitoring Mitochondrial Ph. Chem. Commun 2014, 50, 7184 7187.

(13). Li YH; Wang YJ; Yang S; Zhao YR; Yuan L; Zheng J; Yang RH Hemicyanine-Based High Resolution Ratiometric near-Infrared Fluorescent Probe for Monitoring pH Changes in Vivo. Anal. Chem 2015, 87, 2495-2503. [PubMed: 25635470]

(14). Niu GL; Zhang PP; Liu WM; Wang MQ; Zhang HY; Wu JS; Zhang LP; Wang PF Near-Infrared Probe Based on Rhodamine Derivative for Highly Sensitive and Selective Lysosomal pH Tracking. Anal. Chem 2017, 89, 1922-1929. [PubMed: 28208300]

(15). Vegesna GK; Janjanam J; Bi JH; Luo FT; Zhang JT; Olds C; Tiwari A; Liu HY pH-Activatable near-Infrared Fluorescent Probes for Detection of Lysosomal pH inside Living Cells. J. Mater. Chem. B 2014, 2, 4500-4508.

(16). Wan QQ; Chen SM; Shi W; Li LH; Ma HM Lysosomal Ph Rise During Heat Shock Monitored by a Lysosome-Targeting near-Infrared Ratiometric Fluorescent Probe. Angew. Chem. Int. Ed 2014, 53, 10916-10920.

(17). Wang JB; Xia S; Bi JH; Fang MX; Mazi WF; Zhang YB; Conner N; Luo FT; Lu HP; Liu HY Ratiometric near-Infrared Fluorescent Probes Based on through Bond Energy Transfer and PiConjugation Modulation between Tetraphenylethene and Hemicyanine Moieties for Sensitive Detection of pH Changes in Live Cells. Bioconjugate Chem 2018, 29, 1406-1418.

(18). Zhang SW; Chen TH; Lee HM; Bi JH; Ghosh A; Fang MX; Qian ZC; Xie F; Ainsley J; Christov C; Luo FT; Zhao F; Liu HY Luminescent Probes for Sensitive Detection of $\mathrm{pH}$ Changes in Live Cells through Two near-Infrared Luminescence Channels. ACS Sens 2017, 2, 924-931. [PubMed: 28750522]

(19). Yin J; Hu Y; Yoon J Fluorescent Probes and Bioimaging: Alkali Metals, Alkaline Earth Metals and Ph. Chem. Soc. Rev 2015, 44, 4619-4644. [PubMed: 25317749]

(20). Dong BL; Song XZ; Kong XQ; Wang C; Zhang N; Lin WY A Tumor-Targeting and LysosomeSpecific Two-Photon Fluorescent Probe for Imaging pH Changes in Living Cells. J. Mater. Chem. B 2017, 5, 988-995.

(21). Dong BL; Song XZ; Wang C; Kong XQ; Tang YH; Lin WY Dual Site-Controlled and LysosomeTargeted Intramolecular Charge Transfer-Photoinduced Electron Transfer-Fluorescence Resonance Energy Transfer Fluorescent Probe for Monitoring pH Changes in Living Cells. Anal. Chem 2016, 88, 4085-4091. [PubMed: 26987045] 
(22). He LW; Lin WY; Xu QY; Wei HP A Unique Type of Pyrrole-Based Cyanine Fluorophores with Turn-on and Ratiometric Fluorescence Signals at Different $\mathrm{Ph}$ Regions for Sensing $\mathrm{pH}$ in Enzymes and Living Cells. ACS Applied Materials \& Interfaces 2014, 6, 22326-22333. [PubMed: 25408468]

(23). Zhang YB; Xia S; Fang MX; Mazi W; Zeng YB; Johnston T; Pap A; Luck RL; Liu HY New near-Infrared Rhodamine Dyes with Large Stokes Shifts for Sensitive Sensing of Intracellular pH Changes and Fluctuations. Chem. Commun 2018, 54, 7625-7628.

(24). Zhang RQ; Yan FY; Huang YC; Kong DP; Ye QH; Xu JX; Chen L Rhodamine-Based Ratiometric Fluorescent Probes Based on Excitation Energy Transfer Mechanisms: Construction and Applications in Ratiometric Sensing. RSC Advances 2016, 6, 50732-50760.

(25). Xia S; Wang JB; Bi JH; Wang X; Fang MX; Phillips T; May A; Conner N; Tanasova M; Luo FT; Liu HY Fluorescent Probes Based on Pi-Conjugation Modulation between Hemicyanine and Coumarin Moieties for Ratiometric Detection of $\mathrm{pH}$ Changes in Live Cells with Visible and nearInfrared Channels. Sens. Actuators B Chem 2018, 265, 699-708. [PubMed: 30319177]

(26). Mei J; Huang YH; Tian H Progress and Trends in Aie-Based Bioprobes: A Brief Overview. ACS Applied Materials \& Interfaces 2018, 10, 12217-12261. [PubMed: 29140079]

(27). Fang MX; Adhikari R; Bi JH; Mazi W; Dorh N; Wang JB; Conner N; Ainsley J; KarabenchevaChristova TG; Luo FT; Tiwari A; Liu HY Fluorescent Probes for Sensitive and Selective Detection of Ph Changes in Live Cells in Visible and near-Infrared Channels. J. Mater. Chem. B 2017, 5, 9579-9590. [PubMed: 29607047]

(28). Zhu H; Fan JL; Du JJ; Peng XJ Fluorescent Probes for Sensing and Imaging within Specific Cellular Organelles. Acc. Chem. Res 2016, 49, 2115-2126. [PubMed: 27661761]

(29). Song XB; Hu MY; Wang C; Xiao Y Near-Infrared Fluorescent Probes with Higher Quantum Yields and Neutral Pk(a) Values for the Evaluation of Intracellular pH. RSC Advances 2016, 6, 69641-69646.

(30). Zhang JT; Yang M; Li C; Dorh N; Xie F; Luo FT; Tiwari A; Liu HY Near-Infrared Fluorescent Probes Based on Piperazine-Functionalized BODIPY Dyes for Sensitive Detection of Lysosomal pH. J. Mater. Chem. B 2015, 3, 2173-2184.

(31). Ni Y; Wu JS Far-Red and near Infrared Bodipy Dyes: Synthesis and Applications for Fluorescent pH Probes and Bio-Imaging. Org. Biomol. Chem 2014, 12, 3774-3791. [PubMed: 24781214]

(32). Liu W; Sun R; Ge JF; Xu YJ; Xu Y; Lu JM; Itoh I; Ihara M Reversible near-Infrared pH Probes Based on Benzo a Phenoxazine. Anal. Chem 2013, 85, 7419-7425. [PubMed: 23815155]

(33). Yang HR; Han CM; Zhu XJ; Liu Y; Zhang KY; Liu SJ; Zhao Q; Li FY; Huang W Upconversion Luminescent Chemodosimeter Based on Nir Organic Dye for Monitoring Methylmercury in Vivo. Adv. Funct. Mater 2016, 26, 1945-1953.

(34). Liu Y; Su QQ; Chen M; Dong Y; Shi YB; Feng W; Wu ZY; Li FY Near-Infrared Upconversion Chemodosimeter for in Vivo Detection of Cu2+ in Wilson Disease. Adv. Mater 2016, 28, 66256630. [PubMed: 27185083]

(35). Yuan L; Lin WY; Zhao S; Gao WS; Chen B; He LW; Zhu SS A Unique Approach to Development of near-Infrared Fluorescent Sensors for in Vivo Imaging. J. Am. Chem. Soc 2012, 134, 13510-13523. [PubMed: 22816866]

(36). Wei YF; Cheng D; Ren TB; Li YH; Zeng ZB; Yuan L Design of Nir Chromenylium-Cyanine Fluorophore Library for "Switch-on" and Ratiometric Detection of Bio-Active Species in Vivo. Anal. Chem 2016, 88, 1842-1849. [PubMed: 26730493]

(37). Fang MX; Xia S; Bi JH; Wigstrom TP; Valenzano L; Wang JB; Mazi W; Tanasova M; Luo FT; Liu HY A Cyanine-Based Fluorescent Cassette with Aggregation-Induced Emission for Sensitive Detection of pH Changes in Live Cells. Chem. Commun 2018, 54, 1133-1136.

(38). Parr RG; Yang W Density-Functional Theory of Atoms and Molecules, Oxford Science: Oxford, 1994.

(39). Zhang SW; Adhikari R; Fang MX; Dorh N; Li C; Jaishi M; Zhang JT; Tiwari A; Pati R; Luo FT; Liu HY Near-Infrared Fluorescent Probes with Large Stokes Shifts for Sensing Zn(II) Ions in Living Cells. ACS Sens 2016, 1, 1408-1415. [PubMed: 28845457]

(40). Frisch MJ; Trucks GW; Schlegel HB; Scuseria GE; Robb MA; Cheeseman JR; Scalmani G; Barone V; Mennucci B; Petersson GA; Nakatsuji H; Caricato M; Li X; Hratchian HP; Izmaylov 
AF; Bloino J; Zheng G; Sonnenberg JL; Hada M; Ehara M; Toyota K; Fukuda R; Hasegawa J; Ishida M; Nakajima T; Honda Y; Kitao O; Nakai H; Vreven T; Montgomery JA; Peralta J, J. E; Ogliaro F; Bearpark M; Heyd JJ; Brothers E; Kudin KN; Staroverov VN; Kobayashi R; Normand J; Raghavachari K; Rendell A; Burant JC; Iyengar SS; Tomasi J; Cossi M; Rega N; Millam JM; Klene M; Knox JE; Cross JB; Bakken V; Adamo C; Jaramillo J; Gomperts R; Stratmann RE; Yazyev O; Austin AJ; Cammi R; Pomelli C; Ochterski JW; Martin RL; Morokuma K; Zakrzewski VG; Voth GA; Salvador P; Dannenberg JJ; Dapprich S; Daniels AD; Farkas Ö; Foresman JB; Ortiz JV; Cioslowski J; Fox DJ, Gaussian 09. Gaussian, Inc.: Wallingford CT, 2009.

(41). Bartolotti LJ Time-Dependent Kohn-Sham Density-Functional Theory. Physical Review A 1982, 26, 2243-2244.

(42). Appel H; Gross EKU; Burke K Excitations in Time-Dependent Density-Functional Theory. Phys. Rev. Lett 2003, 90.

(43). Szabo A; Ostlund NS Modern Quantum Chemistry, Dover Publishing: New York, 1996.

(44). Xu W; Zeng ZB; Jiang JH; Chang YT; Yuan L Discerning the Chemistry in Individual Organelles with Small-Molecule Fluorescent Probes. Angew. Chem. Int. Ed 2016, 55, 13658-13699.

(45). Zhang JT; Yang M; Mazi WF; Adhikari K; Fang MX; Xie F; Valenzano L; Tiwari A; Luo FT; Liu HY Unusual Fluorescent Responses of Morpholine-Functionalized Fluorescent Probes to pH Via Manipulation of Bodipy's Homo and Lumo Energy Orbitals for Intracellular pH Detection. ACS Sens 2016, 1, 158-165. [PubMed: 27547822] 

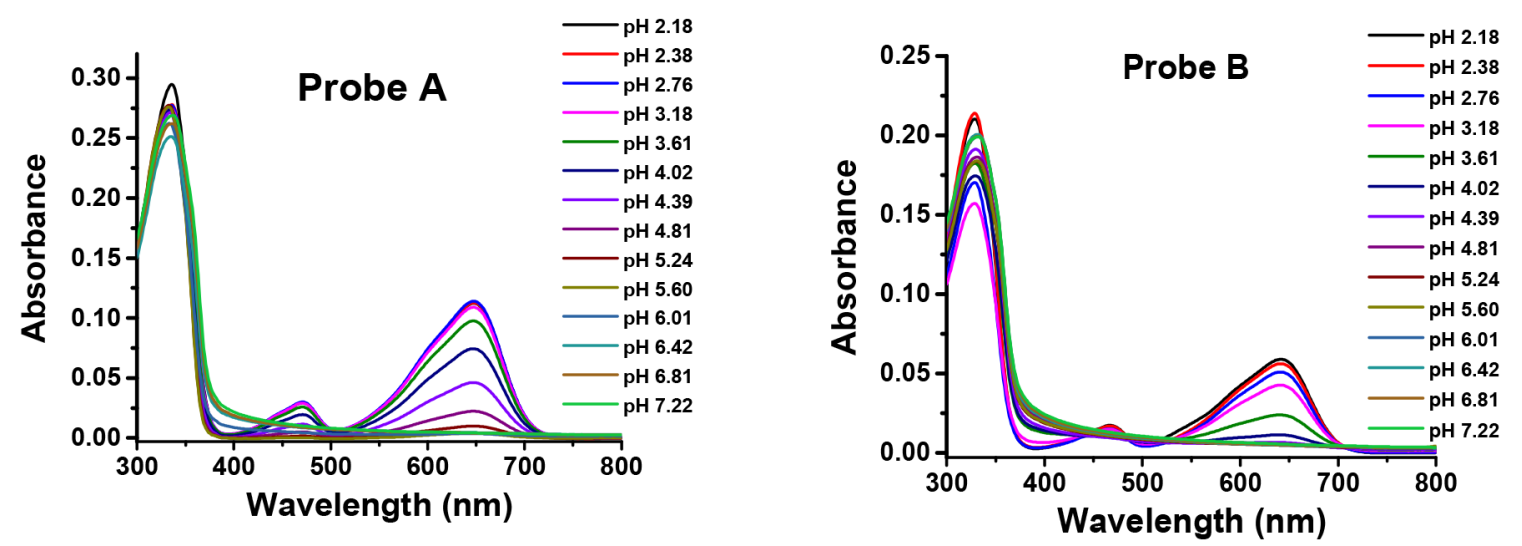

Figure 1.

Absorption spectra for probes $\mathbf{A}$ and $\mathbf{B}(10 \mu \mathrm{M})$ in citrate-phosphate buffers with $1 \%$ ethanol. 

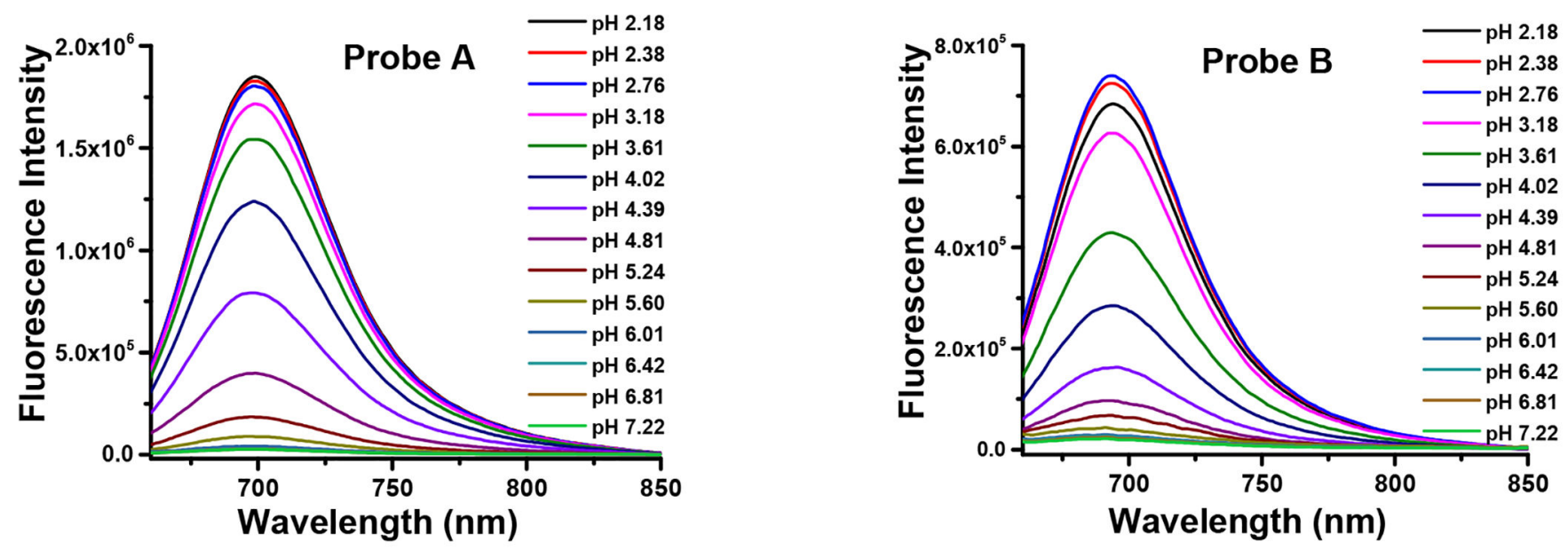

Figure 2.

Stoke-shift emission spectra of $10 \mu \mathrm{M}$ probes $\mathbf{A}$ and $\mathbf{B}$ in citrate-phosphate buffers in the presence of $1 \%$ ethanol under excitation at $645 \mathrm{~nm}$ and $640 \mathrm{~nm}$, respectively. 

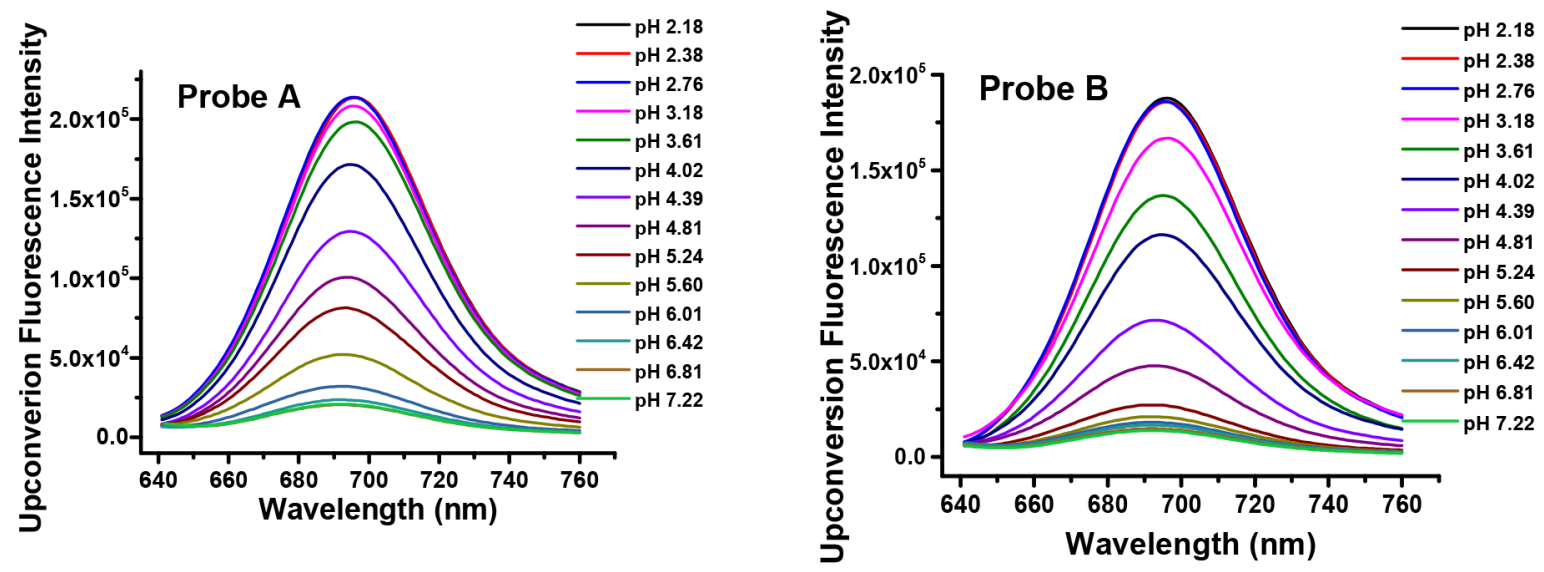

Figure 3.

Anti-Stokes-shift emission spectra of $10 \mu \mathrm{M}$ probes $\mathbf{A}$ and $\mathbf{B}$ in citrate-phosphate buffers in the presence of $1 \%$ ethanol with one-photon $800 \mathrm{~nm}$ excitation. 


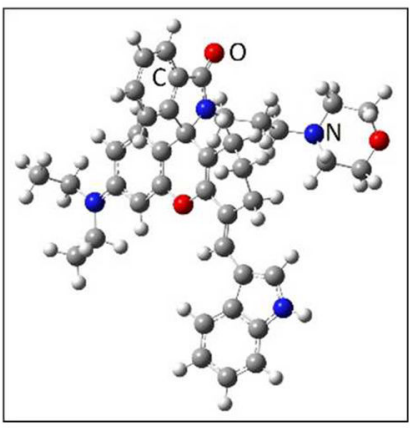

(a) probe $\mathbf{A}$

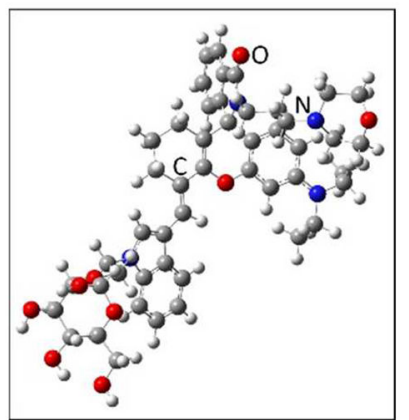

(b) probe $\mathbf{B}$

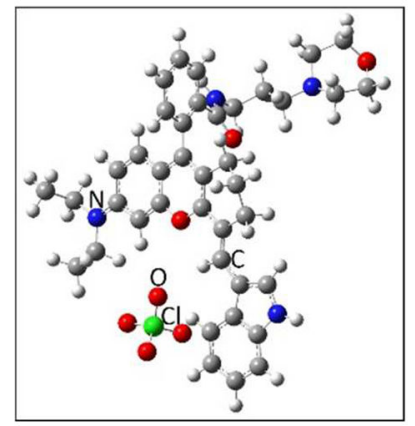

(c) probe $\mathbf{A}$

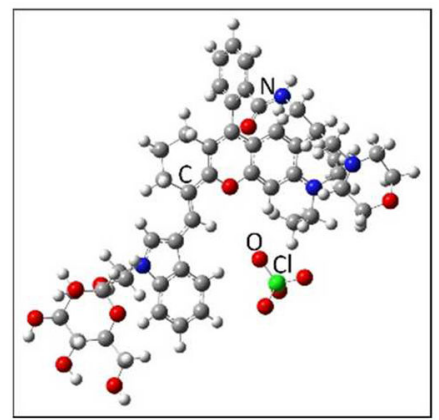

(d) probe $\mathbf{B}$

Figure 4.

Optimized structures of the probes of different configurations in neutral (water) and acidic (formic acid) solvent. (a) \& (b) represent probes $\mathbf{A}$ and $\mathbf{B}$ with closed spirolactam moiety (neutral $\mathrm{pH}$ ) respectively, (c) \& (d) stand for protonated probes $\mathbf{A}$ and $\mathbf{B}$ with opened spirolactam moiety (acidic environment); perchlorate ion $\left(\mathrm{ClO}_{4}^{-}\right)$is taken as a counter ion. 


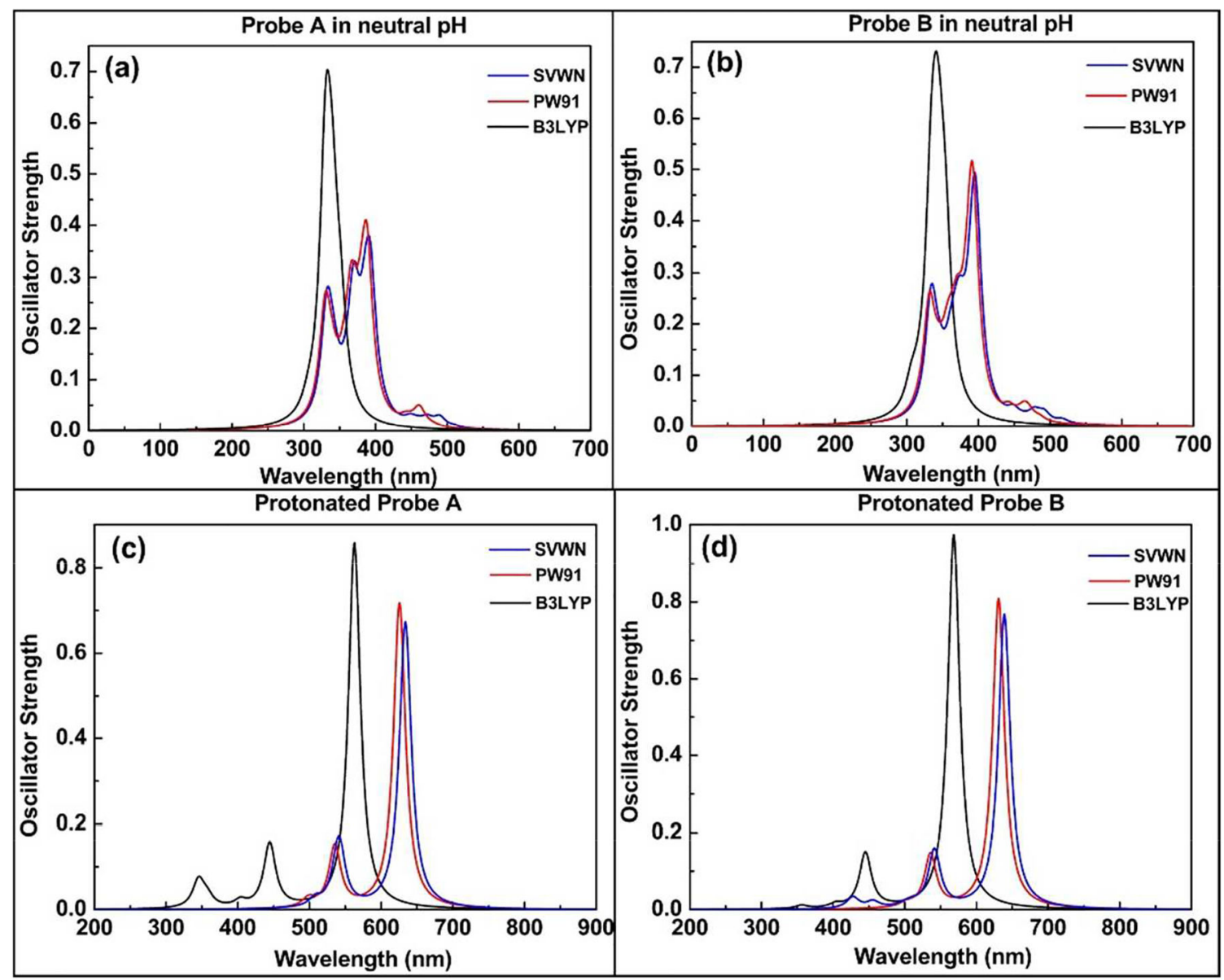

Figure 5.

UV-VIS spectra showing the absorption of different fluorescent probes calculated using TDDFT with three different exchange correlation functionals. (a) \& (b) the probes with closed spirolactam ring (neutral $\mathrm{pH}$ ) respectively, (c) \& (d) the protonated probes with open spirolactam ring (acidic $\mathrm{pH})$, respectively. 

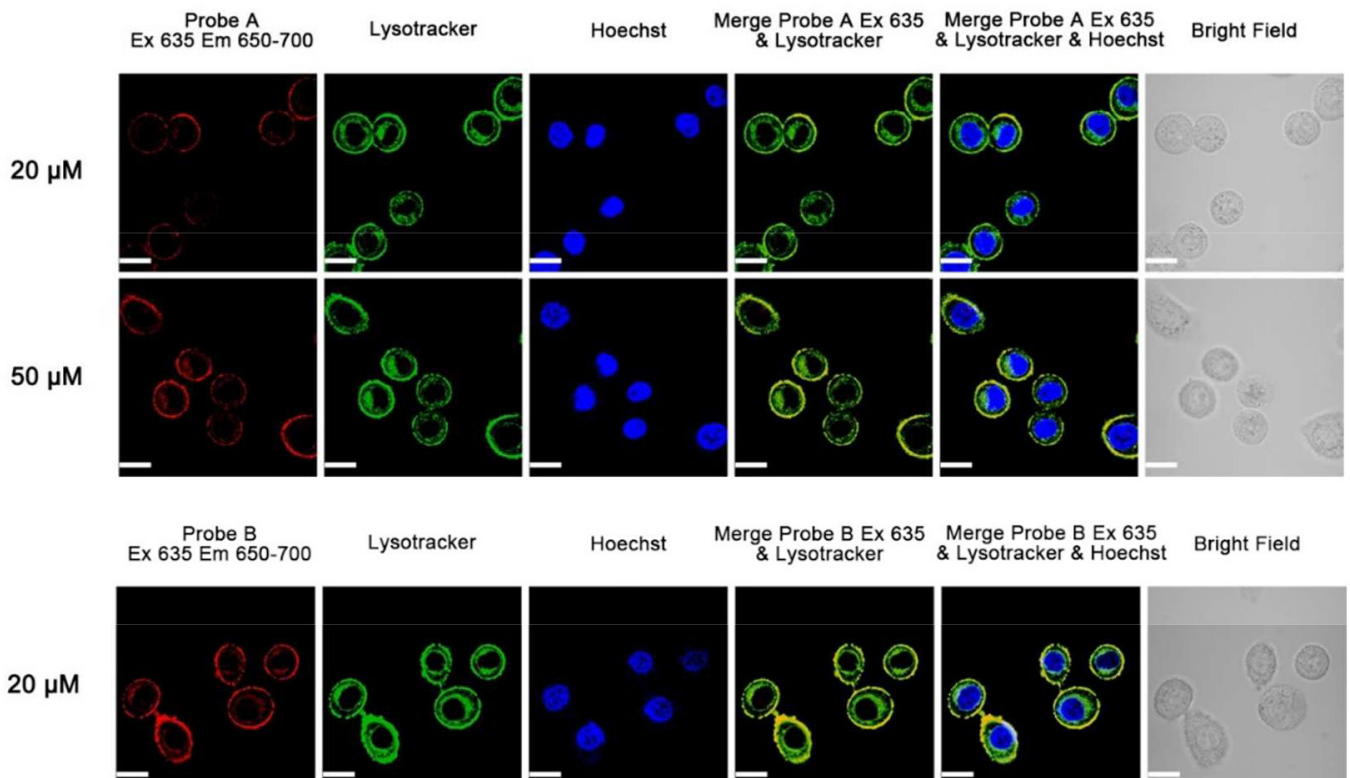

Bright Field

$20 \mu \mathrm{M}$

$50 \mu \mathrm{M}$
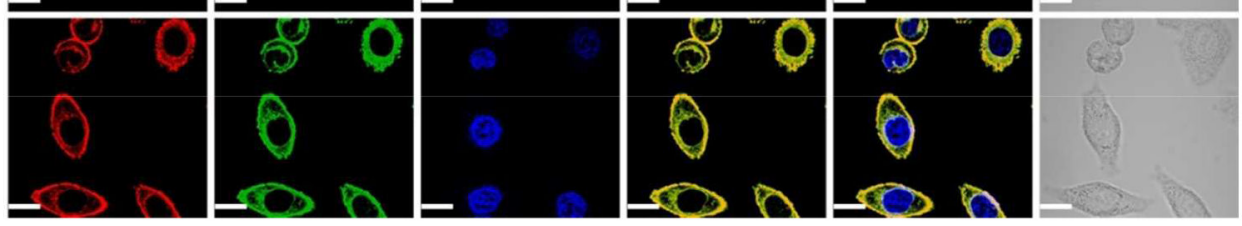

Figure 6.

Images of HeLa cells together with $20 \mu \mathrm{M}$ and $50 \mu \mathrm{M}$ fluorescent probes $\mathbf{A}$ and $\mathbf{B}, 5 \mu \mathrm{M}$ Lysotracker Green and Hoechst stains for $2 \mathrm{~h}$ in cell culture media. Confocal fluorescence microscope (Olympus IX 81) at 60× magnification was employed to collect the images. Blue fluorescence between 425 and $475 \mathrm{~nm}$ of Hoechst was obtained under $405 \mathrm{~nm}$ excitation, and green fluorescence from 525 to $575 \mathrm{~nm}$ of Lysosensor green was acquired for under 488 $\mathrm{nm}$ excitation while near-infrared fluorescence from 650 to $700 \mathrm{~nm}$ of probe $\mathbf{A}$ or $\mathbf{B}$ was collected under $630 \mathrm{~nm}$ excitation. 


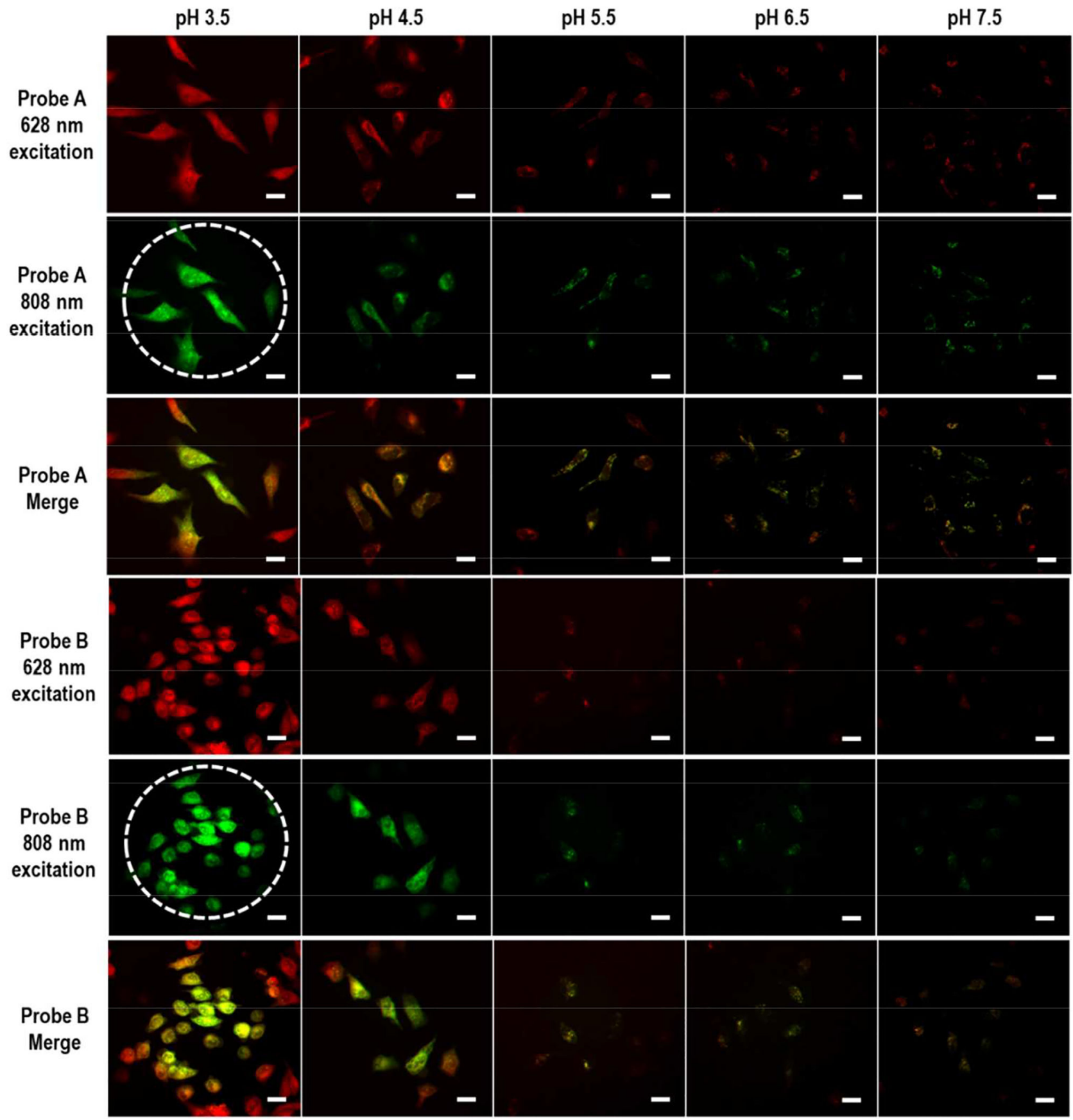

Figure 7.

Stokes-shift and anti-Stokes-shift luminescence images, and their merged images at $40 \times$ magnification of HeLa cells together with $10 \mu \mathrm{M}$ of probes $\mathbf{A}$ and $\mathbf{B}$ in buffers with $\mathrm{pH}$ from 3.5, 4.5, 5.5, 6.5 to 7.5 together with $5 \mathrm{mg} / \mathrm{L}$ nigericin. Stokes-shift luminescence images were obtained with a band-pass filter Ex608-648/Em672-712 nm while anti-Stokes-shift luminescence images were measured from 672 to $712 \mathrm{~nm}$ under excitation at $808 \mathrm{~nm}$ with a $\mathrm{CW}$ laser. Note that dashed line circle in anti-Stokes-shift luminescence images indicates the 
$808 \mathrm{~nm}$ laser light spot. Images were performed by the lamp-based Olympus IX-71 inverted fluorescence microscope with scale bars of $20 \mu \mathrm{m}$. 


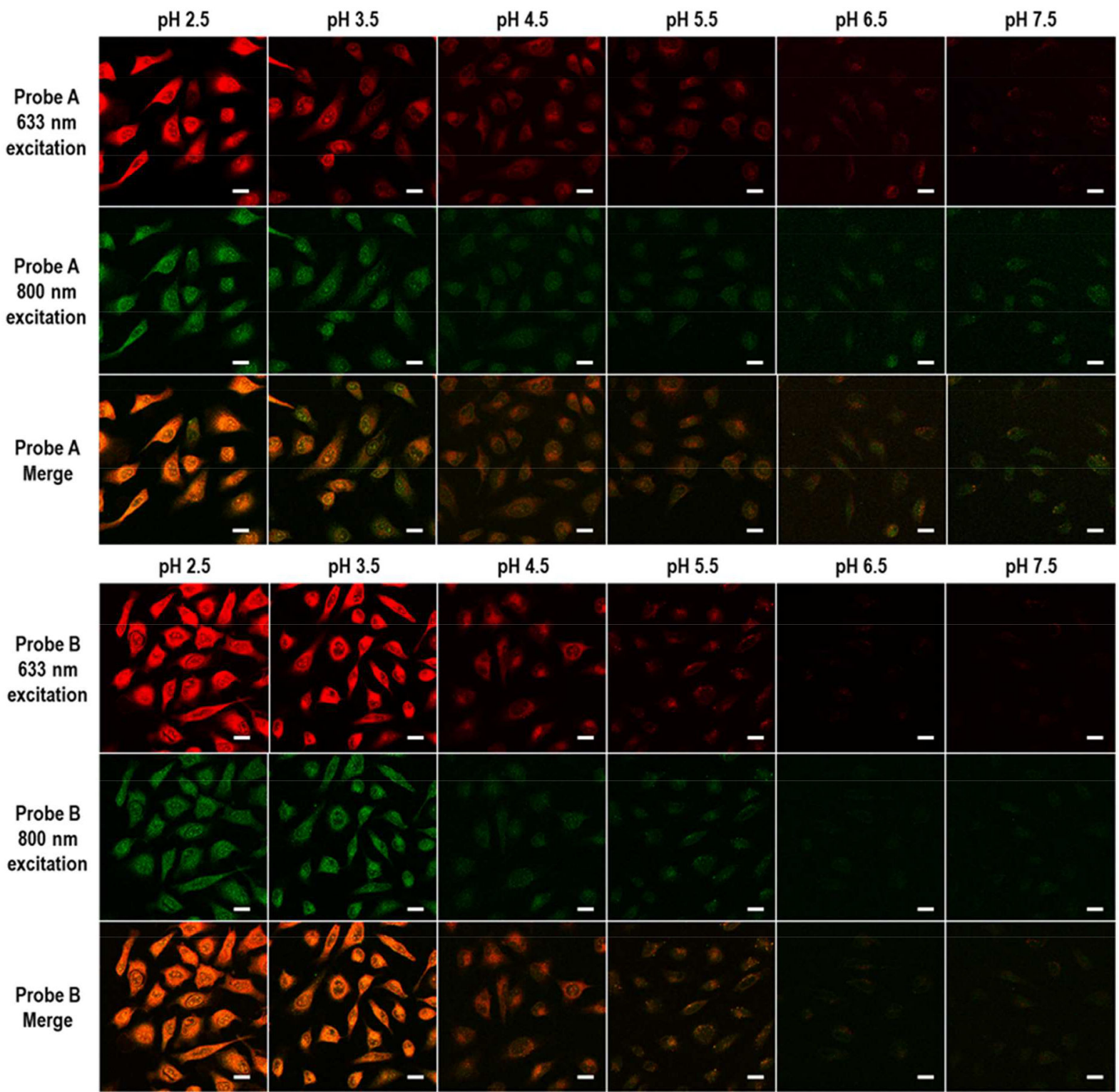

Figure 8.

Stokes-shift and anti-Stokes-shift luminescence images with scale bars of $20 \mu \mathrm{m}$ at $40 \times$ magnification of Hela cells together with $10 \mu \mathrm{M}$ of probes $\mathbf{A}$ and $\mathbf{B}$ in $\mathrm{pH}$ buffers from 2.5, 3.5, 4.5, 5.5, 6.5 to 7.5 holding $5 \mathrm{mg} / \mathrm{L}$ nigericin. Stokes-shift luminescence image (redcolor) was acquired under $633 \mathrm{~nm}$ excitation with HeNe continuous wave laser while antiStokes-shift luminescence image (green-color) was obtained under $800 \mathrm{~nm}$ excitationt with a pulse laser. Both Stokes-shift and anti-Stokes-shift luminescence were collected from 650 to $700 \mathrm{~nm}$ by using Zeiss LSM510 confocal fluorescence microscope. 
Probe A HeLa cells

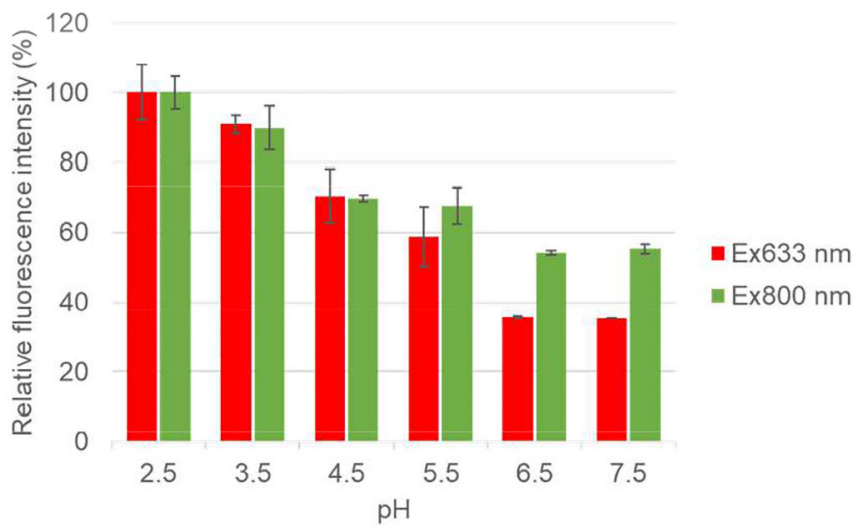

Probe B HeLa cells

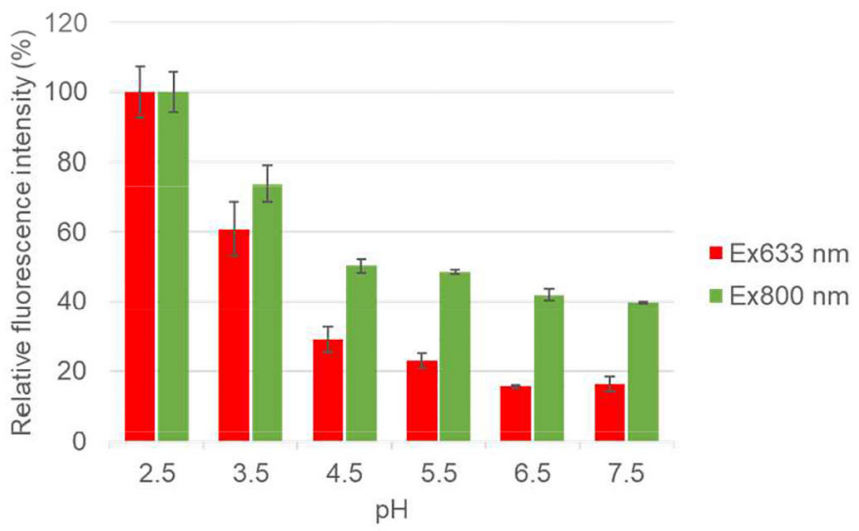

Figure 9.

Cellular luminescence intensity of probes $\mathbf{A}$ and $\mathbf{B}$ versus $\mathrm{pH}$ obtained from cellular luminescence images in Figure 8 under $633 \mathrm{~nm}$ and $800 \mathrm{~nm}$ excitation. 

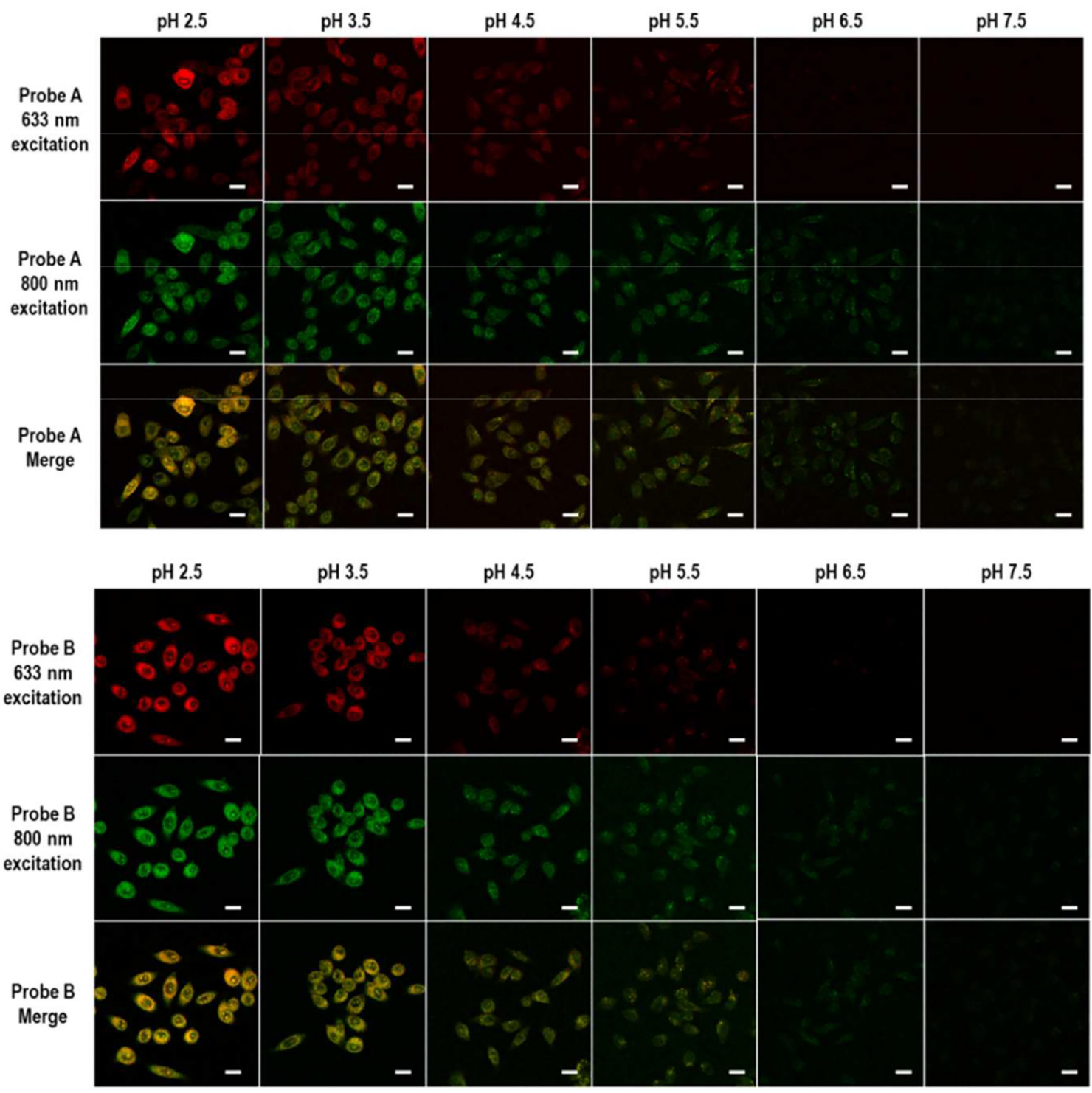

Figure 10.

Stokes-shift and anti-Stokes-shift luminescence images with scale bars of $20 \mu \mathrm{m}$ at $40 \times$ magnification of $\mathrm{KB}$ cells together with $10 \mu \mathrm{M}$ of probes $\mathbf{A}$ and $\mathbf{B}$ in $\mathrm{pH}$ buffers from 2.5, 3.5, 4.5, 5.5, 6.5 to 7.5 holding $5 \mathrm{mg} / \mathrm{L}$ nigericin. Stokes-shift luminescence image (redcolor) was acquired under $633 \mathrm{~nm}$ excitation with a HeNe continuous wave laser while antiStokes-shift luminescence image (green-color) was obtained under $800 \mathrm{~nm}$ excitation with a pulse laser. Both Stokes-shift and anti-Stokes-shift luminescence were collected from 650 to $700 \mathrm{~nm}$ by Zeiss LSM510 confocal fluorescence microscope. 
Probe A KB cells

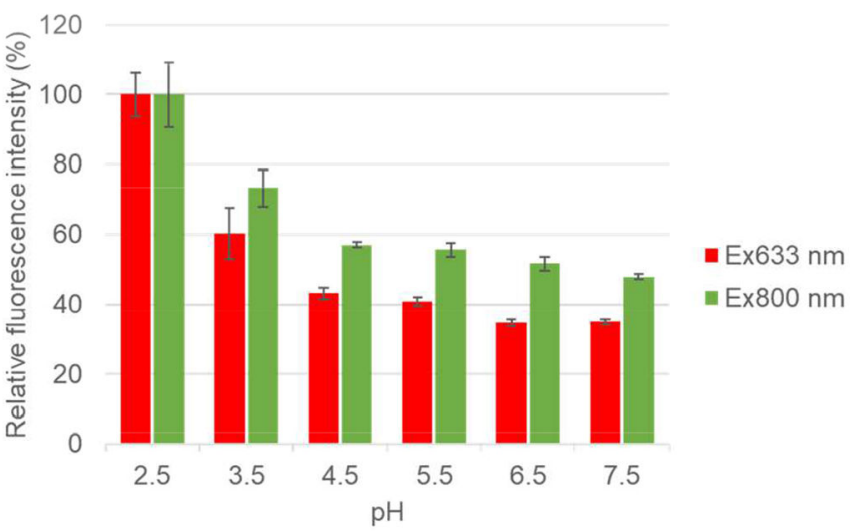

Probe B KB cells

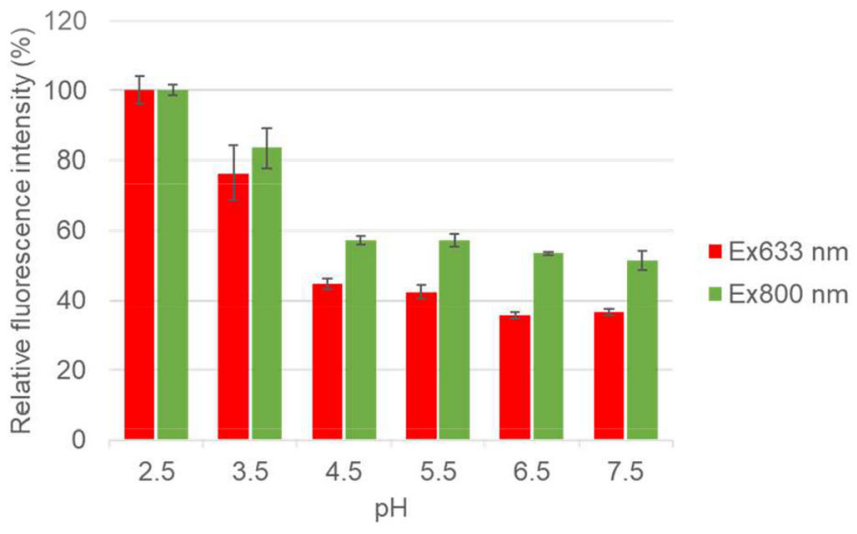

Figure 11.

Cellular luminescence intensity of probes $\mathbf{A}$ and $\mathbf{B}$ versus $\mathrm{pH}$ obtained from cellular luminescence images in Figure 10 under $633 \mathrm{~nm}$ and $800 \mathrm{~nm}$ excitation. 


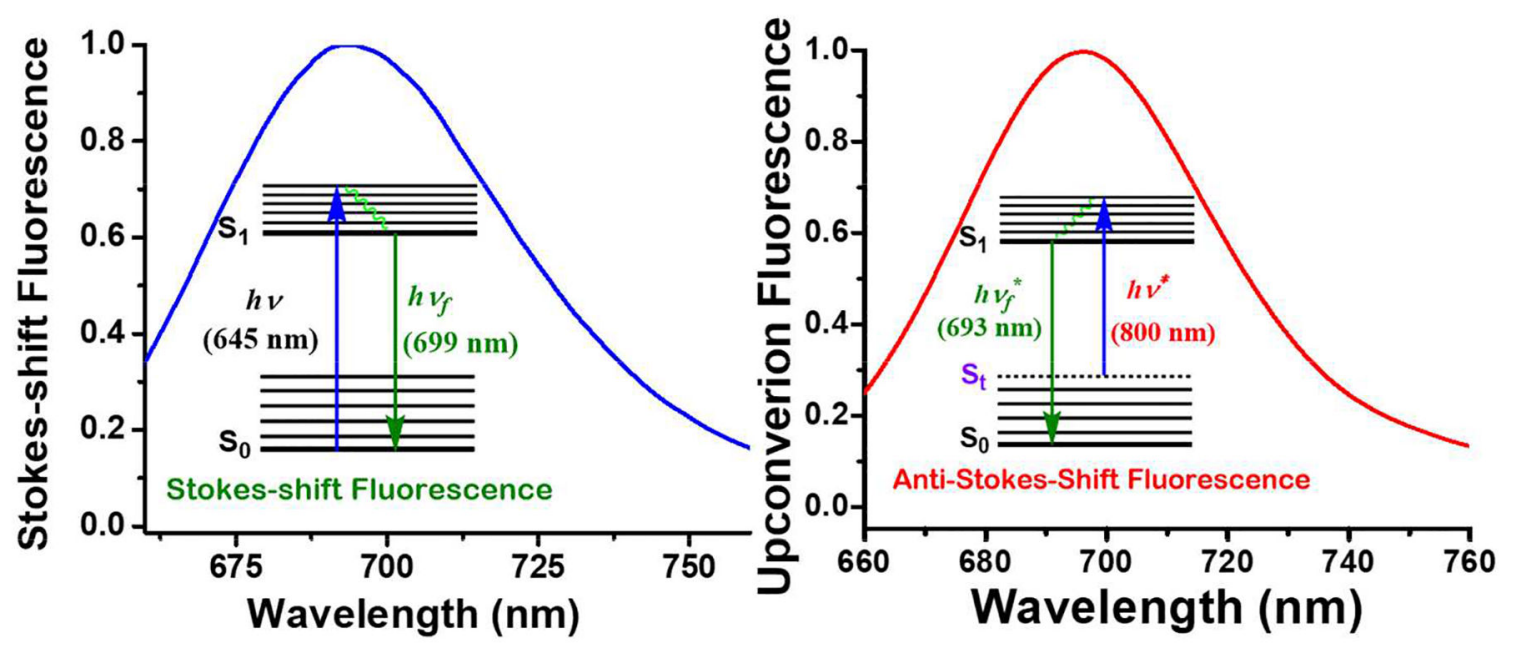

$S_{t}$ : thermally excited vibrational-rotational energy levels

Scheme 1.

Stokes-shift and one-photon anti-Stokes-shift fluorescence mechanism. 


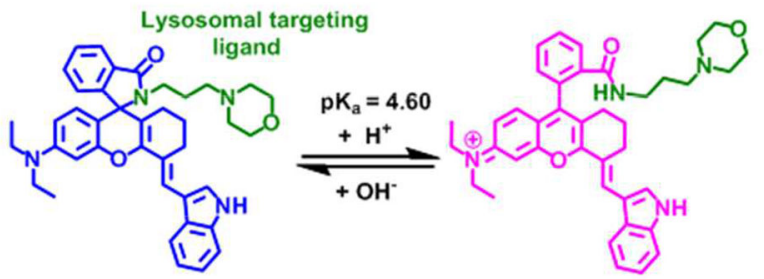

Fluorescent probe A

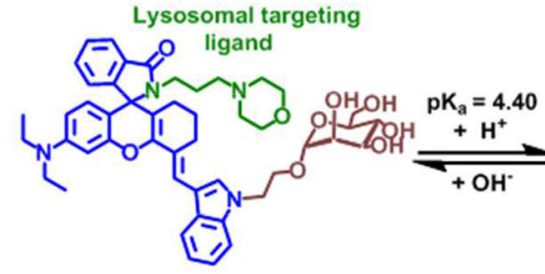

Fluorescent probe B

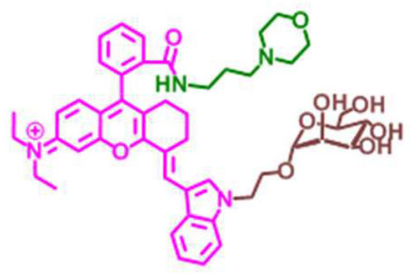

Scheme 2.

Probe structural responses to $\mathrm{pH}$ changes 

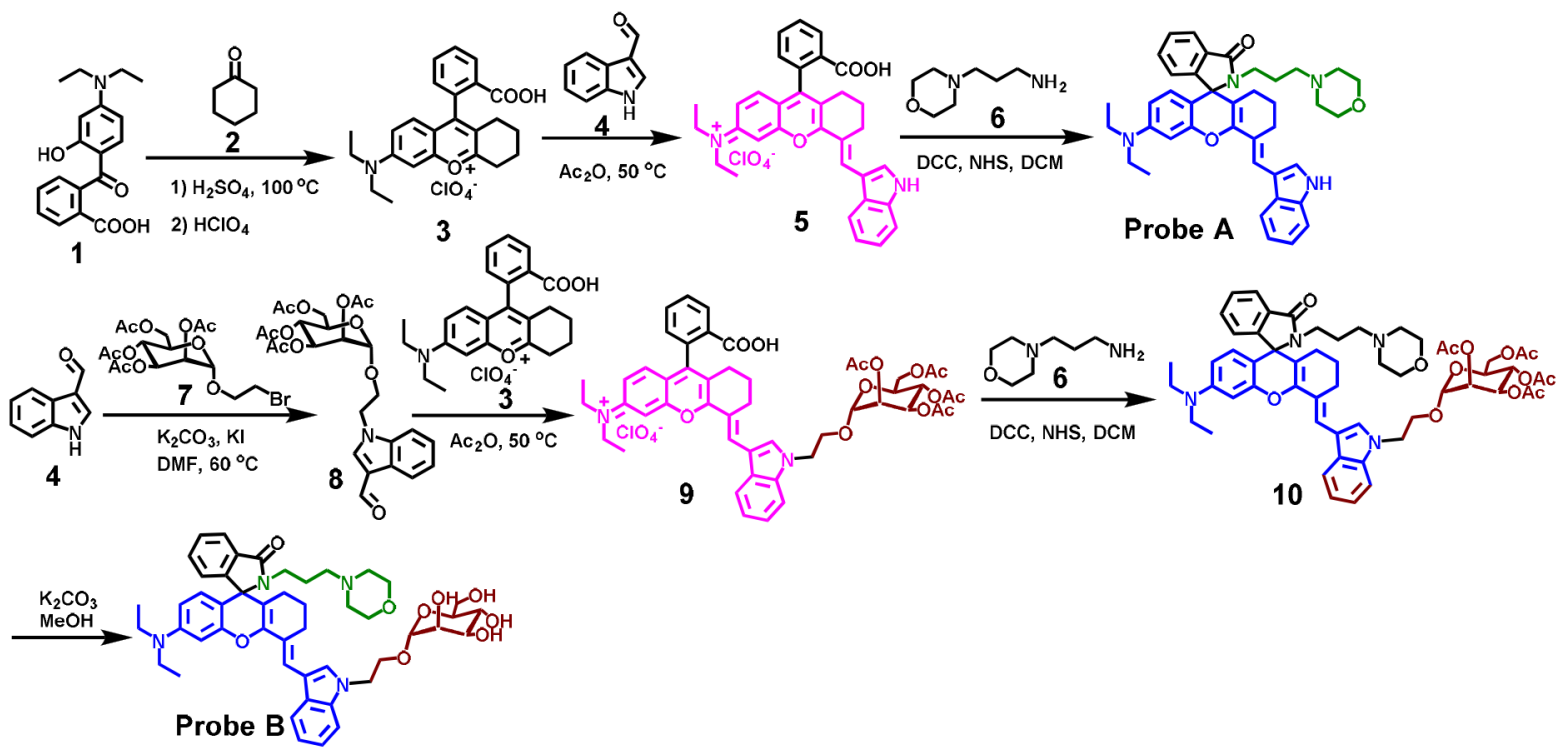

Scheme 3.

Synthetic approach to the probes. 